Original Paper http://ajol.info/index.php/ijbcs http://indexmedicus.afro.who.int

\title{
Lead concentrations in sediments and mollusc gastropod from Vridi Canal, Côte d'Ivoire
}

\author{
Adjoumani Rodrigue KOUAKOU ${ }^{*}$, N'guessan Louis Berenger KOUASSI ${ }^{2}$,
} Edmond Konan KOUASSI ${ }^{1}$, Albert TROKOUREY ${ }^{3}$, Benjamin Kouassi YAO $^{4}$ and Kopoin ADOUBY ${ }^{4}$

\author{
${ }^{1}$ Laboratoire de Thermodynamique et Physico-Chimie du Milieu, UFR Sciences Fondamentales et Appliquées ; \\ Université Nangui Abrogoua ; 02 BP 801 Abidjan 02, Côte d'Ivoire. \\ ${ }^{2}$ Université Peleforo Gon Coulibaly, BP 1328 Korhogo, Côte d'Ivoire. \\ ${ }^{3}$ Laboratoire de Chimie Physique, Université Félix Houphouët Boigny, 22 BP 582 Abidjan, Côte d'Ivoire. \\ ${ }^{4}$ Laboratoire des Procédés industriels de Synthèse, de l'Environnement et des Energies Nouvelles, Institut \\ National Polytechniques Felix Houphouët Boigny (INPHB), BP 1093 Yamoussoukro, Côte d'Ivoire. \\ *Corresponding author; E-mail: adjoumanro@gmail.com
}

\begin{tabular}{lll}
\hline Received: 29012019 & Accepted: 26062019 & Published: 28022021 \\
\hline
\end{tabular}

\begin{abstract}
Lead $(\mathrm{Pb})$ is one of the most frequent and toxic contaminant in the environment. It can be bioaccumulated by marine organisms through contaminated sediments as well as their food chains. The current study aimed at investigating $\mathrm{Pb}$ occurrence in the sediments and gastropod $P$. haemastostoma from Vridi Canal. Sediment samples were taken using a Van Veen steel grab of $0.02 \mathrm{~m}^{2}$ area, sealed in plastic bags and transported to the laboratory at $4{ }^{\circ} \mathrm{C}$. Gastropod $P$. haemastostoma species were collected manually using gloves, and then placed in polyethylene plastic bags. The different concentrations were determined using atomic absorption spectrometer Varian AA 20. The results showed seasonal variability of $\mathrm{Pb}$ concentrations in sediments and $P$. haemastostoma. In the both matrices, $\mathrm{Pb}$ exhibited the same trend in the distribution between the seasons. This study also mentioned that sediments were highly contaminated by $\mathrm{Pb}(54.27-134.71 \mathrm{mg} / \mathrm{kg})$. Vridi Canal was found to be one of the most contaminated seaport area. Pb levels $(49.55-104.19 \mathrm{mg} / \mathrm{kg})$ in $P$. haemastostoma exceeding the maximum permitted levels according to the United Nations Food and Agriculture Organization (FAO). This research demonstrated that sediments having lower ecological risk may be resulting in lower tissue $\mathrm{Pb}$ of $P$. haemastostoma.
\end{abstract}

(C) 2021 International Formulae Group. All rights reserved.

Keywords: Metal $\mathrm{Pb}$, sediment, $P$. haemastostoma, seasonal variation.

\section{INTRODUCTION}

Lead, known to be toxic metal with no nutrient values, finds its way into the aquatic environment via atmospheric inputs as well as from leaded gaz leaking from boats (Berto et al., 2012). Its presence in water systems, even at low concentrations causes its incorporation into the food chain, which could result in a wide variety of adverse effects in organisms and humans (Baby et al., 2010; Youssao et al., 2011; Kantati et al., 2013; Zhang et al., 2017; Gope et al., 2017). However, determination of lead contamination level in aquatic system is important in order to control its pollution in the environment. Several studies have shown that tropical estuarine sediments were highly 
contaminated by $\mathrm{Pb}$ (Chakraborty et al., 2015; Kouassi et al., 2015; Yao and Kouassi, 2015; Chen et al., 2016; Botwe et al., 2017). However, these studies have not focused on seasonal accumulation of $\mathrm{Pb}$ in seaport sediments. Studies on the assessment of $\mathrm{Pb}$ contamination in tropical seaport sediments are in its infancy.

In Côte d'Ivoire, Vridi Canal is the unique way to enter and exit of Abidjan seaport area (Kouakou et al., 2016a). The intense ship traffic and the high fishing fleet increase the potential risk of lead contamination in the surface sediments of this area. More recently, in order to enlarge the Vridi Canal, intense dredging has become a very common activity leading to relevant sediment resuspension from which $\mathrm{Pb}$ can be easily released into water column (Xie et al., 2016). Therefore, it is crucial to assess $\mathrm{Pb}$ concentration in Vridi seaport sediments.

$\mathrm{Pb}$ accumulated in sediments could be released into water column under the variation of various physical and chemical parameters such as $\mathrm{pH}$, ionic strength. Thus, $\mathrm{Pb}$ release into water column could be accumulated by biota. For this reason, many researches were carried out on $\mathrm{Pb}$ concentration in organisms such as gastropod mollusks (Xiaobo et al., 2009; Ragi et al., 2017; Baltas et al., 2017; Mejdoub et al., 2018). These studies showed those gastropods $\mathrm{Pb}$ concentrations exceeding WHO safe limits. Some gastropods species represent a source of cheap protein for the population. This is the case of Vridi Canal where gastropods $P$. haemastostoma are highly consumed by habitants. Moreover, Kouakou et al. (2016a) have reported high levels of $\mathrm{Cd}$ and $\mathrm{Zn}$ in P. haemastostoma in Vridi Canal. However, there is no report about $\mathrm{Pb}$ in the tissues of $P$. haemastostoma in this area. This study aimed at investigating the concentrations of lead simultaneously in sediments and in the tissues of $P$. haemastostoma from the Vridi Canal. To address this objective: (i) the seasonal variations of $\mathrm{Pb}$ concentrations in sediments and in P. haemastostoma were assessed, (ii) the relationship between lead content in the sediments and its bioaccumulation in $P$. haemastostoma was investigated, and (iii) the ecological risks (Er) of sediments and the bioaccumulation factor (BAF) for $\mathrm{Pb}$ were determined.

\section{MATERIALS AND METHODS \\ Description of the study area}

This study focused on an important Canal of Abidjan seaport (the economic capital of Côte d'Ivoire). Vridi Canal is an artificial Canal created in 1954 and located in the southern part of Abidjan (Kouakou et al., $2016 \mathrm{a}$, b). It is chosen because of its proximity to most of the industrial and maritime activities taking place, such as maritime transport and fishing, and the company of oil Refinery. This Canal possesses a navigable depth of $15 \mathrm{~m}$ with a length of $2.7 \mathrm{~km}$, and a width of about $370 \mathrm{~m}$. It receives domestic raw sewage, household waste, and industrial wastes from its neighbourhood (Kouakou et al., 2016a).

\section{Sampling and treatment of sediment}

The sediment samples were collected between February 2015 and September 2015 (dry season, rainy season and flooding season) from different sites (Figure 1). Three significant stations representative of each site were selected upstream, midstream, and downstream. Sediment samples were collected at each station using a Van Veen stainless steel grab of $0.02 \mathrm{~m}^{2}$ area, following USEPA (2001). Then sediment samples were put into small plastic bags and kept in a cooler at $4{ }^{\circ} \mathrm{C}$. All samples were transported to laboratory and subsequently stored in a freezer at $-20^{\circ} \mathrm{C}$. The sediments samples were treated according to the treatment method described by Saleem et al. (2015).

$\mathrm{pH}$ was determined using standard procedures (Radojevic and Bashkin, 1999). Organic carbon was determined using Walkey-Black method (Radojevic and Bashkin, 1999). The $\mathrm{pH}$ was measured using 1:2 sediment, water ratio with the $\mathrm{pH}$ meter. Grain size distribution is one of the most important characteristics of sediment. Protocol used to separate the different sediment is the 
pipette method of Robinson-Köln (Radojevic and Bashkin, 1999).

A mass of $0.2 \mathrm{~g}$ of each of the homogenized sediment was digested in closed Teflon bomb with a mixture of $1 \mathrm{ml}$ of aqua regia $\left(\mathrm{HNO}_{3}: \mathrm{HCl} ; 1: 3, \mathrm{~V} / \mathrm{V}\right)$ and $3 \mathrm{ml}$ of $\mathrm{HF}$, heated to $100{ }^{\circ} \mathrm{C}$ during $3 \mathrm{~h}$ in a water bath. After cooling, a volume of $20 \mathrm{ml}$ of $\mathrm{H}_{3} \mathrm{BO}_{4}$ $(140 \mathrm{~g} / \mathrm{L})$ was added to each Teflon bomb to mask free fluoride ions in solution and redissolve fluoride precipitates (Kouassi et al., 2015). The final volume was made up to 50 $\mathrm{ml}$ with $2 \%$ ultrapure $\mathrm{HNO}_{3}$. The solutions were filtered and stored in polyethylene flasks for later determination of lead content.

\section{Sampling and treatment of gastropod}

Purpurea haemastostoma was collected from the same sites and during the same seasons as for sediments. Gastropod $P$. haemastostoma species were collected manually using gloves, and then placed in polyethylene plastic bags (Bakary et al., 2015). The individuals were selected for the following sizes of shells: $4 \mathrm{~cm}$ for $P$. haemastostoma. Approximately 144 of gastropod samples were collected between February 2015 and September 2015. After sampling, the samples were treated according to Chiffoleau (2003) before analysis.

\section{Total digestion of the soft tissues of gastropod}

The digestion of soft tissues was made according to the method described by Chiffoleau (2003). $0.2 \mathrm{~g}$ of each of the homogenized soft tissues was placed in a Teflon bomb, then $4 \mathrm{ml}$ of concentrated $\mathrm{HNO}_{3}$ (65\%) was added and hold for all night for a pre-digestion and digested on a water bath (above $100{ }^{\circ} \mathrm{C}$ ) for $3 \mathrm{~h}$. After cooling, the solution was filtered, stored in polyethylene flasks and made the filtrate up to $50 \mathrm{ml}$ with deionized water. Blank digestion was also made to quantify possible contamination.

\section{Determination of lead concentration}

Lead contents were determined by using an air-acetylene flame atomic adsorption spectrometer (Varian SpectrAA 20). The detection limit was $0.003 \mathrm{mg} / \mathrm{kg}$. In addition, accuracy and precision of analysis was checked by replicate measurements of standard reference materials (BCSS-1, National Research Council Canada, DORM-2 dogfish muscle). The measured concentrations fell within the range of certified values, and the recoveries varied between $94 \%$ and $108 \%$.

\section{Bioaccumulation factor (BAF) and ecological risk index $\left(E_{r}{ }^{i}\right)$}

The accumulation of $\mathrm{Pb}$ from sediment in the gastropod $P$. haemastostoma was estimated according to the following BAF equation:

$$
\text { BAF }=\frac{\mathrm{C}_{\text {gastropod }}}{\mathrm{C}_{\text {gediment }}}
$$

Where $\mathrm{C}_{\text {gastropod }}(\mathrm{mg} / \mathrm{kg})$ and Csediment $(\mathrm{mg} / \mathrm{kg})$ are the concentrations of $\mathrm{Pb}$ in $P$. haemastostoma and sediment, respectively. When BAF value exceeds 1 , metal is likely to concentrate in $P$. haemastostoma relative to the sediment.

Ecological risk associated with the presence of $\mathrm{Pb}$ in sediment was calculated using the following equations developed by Hakanson (1980).

$$
\begin{aligned}
c_{f}^{i} & =\frac{c_{i}}{c_{n}^{i}} \\
E_{r}^{i} & =T_{r}^{i} \times C_{f}^{i}
\end{aligned}
$$

Where $C_{f}$ is the contamination factor of $\mathrm{Pb}$ in the sediment sample, $\mathrm{C}_{\mathrm{i}}$ is the analyzed $\mathrm{Pb}$ concentration $(\mathrm{mg} / \mathrm{kg})$ in the sediment sample, and $\mathrm{C}_{\mathrm{n}}$ is the background concentration of $\mathrm{Pb}(17 \mathrm{mg} / \mathrm{kg})$ in the Upper Continental Crust given by Wedepoh (1995). $\mathrm{E}_{\mathrm{r}}$ is the ecological risk index of $\mathrm{Pb}$ and the toxicity coefficient $\mathrm{T}_{\mathrm{r}}$ represents the toxicity and biological sensitivity to $\mathrm{Pb}$. The value of $\mathrm{T}_{\mathrm{r}}$ for $\mathrm{Pb}$ is 5 (Hakanson, 1980).

An Er value $<40$ corresponds to low risk; $40<\mathrm{Er}<80$ to moderate risk; $80<\mathrm{Er}<$ 160 considerable risk; $160<\mathrm{Er}<320$ to high risk, and $\mathrm{Er} \geq 320$ to very high risk (Hakanson, 1980). 


\section{Statistical analysis}

The analysis of variance (ANOVA one way) was used to evaluate the difference between the months. Then, Tukey test (Honest significant difference) was performed whenever significant difference was found in
ANOVA. Differences were considered significant at $p$ values $<0.05$. Statistical analyses (mean value, minimum, maximum, and correlation) were carried out with Statistica 7.1 software.

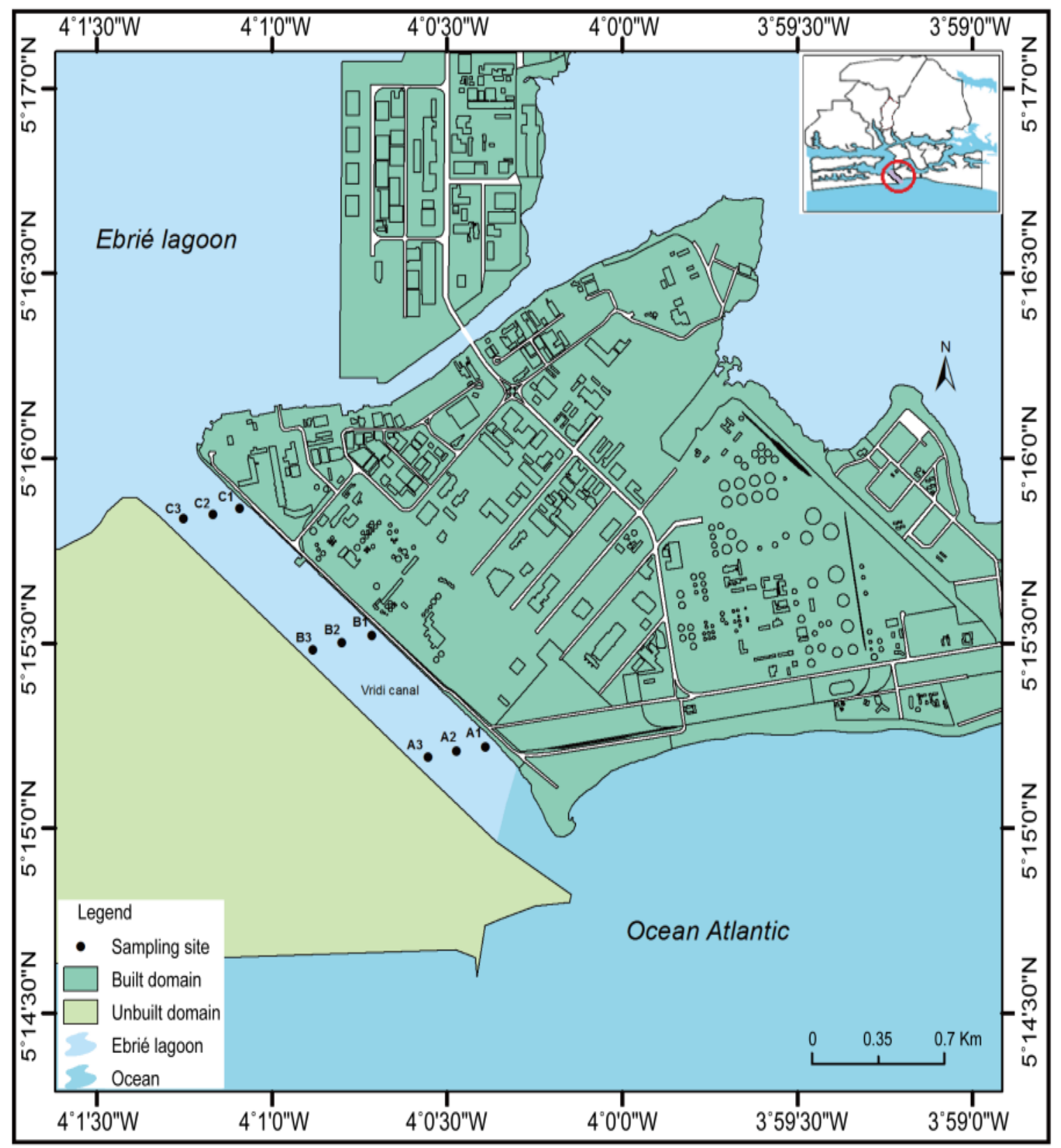

Figure 1: Map of the study area showing sampling sites. 


\section{RESULTS}

\section{Physico-chemical parameters and sediment grain sizes}

The physico-chemical parameters of sediment samples are given in Table 1.

The averages values of $\mathrm{pH}$, and TOC varied between $7.41 \pm 0.31$ and $8.42 \pm 0.19$, and between $0.28 \pm 0.24 \%$ and $0.94 \pm 0.8 \%$, respectively. Sediment texture results indicated that sediments were mainly composed by sand particles with an average percentage ranged from $56.77 \pm 5.14 \%$ to $89.69 \pm 4.14 \%$ (Table 1). One-way ANOVA analysis $(p<0.05)$ showed that $\mathrm{pH}$, TOC and sediment grain size composition varied significantly with the seasons.

\section{Total concentrations of $\mathrm{Pb}$ in sediments and bioaccumulation of $\mathrm{Pb}$ in $P$. haemastostoma}

The seasonal variation of $\mathrm{Pb}$ concentration in Vridi Canal sediments is given in Figure 2. The ranges of $\mathrm{Pb}$ concentrations were $(108.84 \pm 37.87-134.71$ $\pm 54.77) \mathrm{mg} / \mathrm{kg},(52.65 \pm 21.50-72.23 \pm$ $19.08) \mathrm{mg} / \mathrm{kg}$ and $(92.24 \pm 28.34-115.35 \pm$ 28.32) $\mathrm{mg} / \mathrm{kg}$, during the dry season (February-March), the rainy season (AprilJune) and the flood season (July-September), respectively. These values were higher than the pre-industrial values $\left(17 \mathrm{mg} \mathrm{kg}^{-1}\right)$ in the Upper Continental Crust (UCC) (Wedepohl, 1995). Significant differences (ANOVA, $\mathrm{p}<$ $0.05)$ were observed between $\mathrm{Pb}$ concentration in the dry season and the rainy season, and $\mathrm{Pb}$ concentration in the rainy season and the flood season.

As displayed in Figure 2, the average concentrations of lead in the soft tissues of $P$. haemastostoma vary from $49.55 \pm 21.49$ $\mathrm{mg} / \mathrm{kg}$ (May) to $104.19 \pm 28.32 \mathrm{mg} / \mathrm{kg}$ (August). During the sampling period, in $P$. haemastostoma $\mathrm{Pb}$ contents exceeded the maximum permissible levels $(2 \mathrm{mg} / \mathrm{kg})$ according to the United Nations Food and Agriculture Organization (FAO). Total concentration of $\mathrm{Pb}$ in $P$. haemastostoma showed significant differences (ANOVA, $\mathrm{P}<$ 0.05 ) between the dry and rainy seasons, and between the rainy and flood seasons.

\section{Relationship between $\mathrm{Pb}$ in sediment and $\mathrm{Pb}$ bioaccumulation in $\boldsymbol{P}$. haemastostoma}

The linear regression showed a significant correlation $\left(r^{2}=0.82 ; N=72\right)$ between $\mathrm{Pb}$ concentrations in the sediments and $P$. haemastostoma $\mathrm{Pb}$ concentrations (Figure 3). $\mathrm{Pb}$ bioaccumulation in $P$. haemastostoma gradually increased with the increasing concentrations of $\mathrm{Pb}$ in the sediments.

\section{Correlation between bioaccumulation factor (BAF) and ecological risk index $\left(E_{r}^{i}\right)$}

Table 2 gives the values of bioaccumulation factor (BAF) and ecological risk index $\left(\mathrm{E}_{\mathrm{r}}^{\mathrm{i}}\right)$. Average $\mathrm{BAF}$ values were ranged from $0.74 \pm 0.35$ (March) to $0.97 \pm$ 0.30 (April), with no significant difference (ANOVA, p < 0.05) between the seasons. $\mathrm{BAF}$ of $\mathrm{Pb}$ indicated values lower than the unity during the sampling period. The ecological risk index $\left(\mathrm{E}_{\mathrm{r}}^{\mathrm{i}}\right)$ values for $\mathrm{Pb}$ varied between $15.48 \pm 6.15$ (April) and $39.62 \pm$ 10.06 (March). The average values of Er were significantly lower $(\mathrm{p}<0.05)$ in the rainy season compared to those in the dry and flood seasons. The Er values were lower than 40, indicating low risk for $\mathrm{Pb}$ in sediments of Vridi Canal. Figure 4 shows the linear regression between BAF and Er. The results revealed that there was not significant correlation $\left(\mathrm{r}^{2}=0.056 ; \mathrm{N}=72\right)$ between BAF and $\mathrm{Er}$. 
Table 1: Physico-chemical parameters and sediment grain sizes.

\begin{tabular}{lccccc}
\hline & PH & TOC (\%) & Clay (\%) & Silt (\%) & Sand (\%) \\
\hline February & $8.06 \pm 0.60$ & $0.72 \pm 0.47$ & $13.04 \pm 2.75$ & $26.12 \pm 3.67$ & $60.84 \pm 5.29$ \\
March & $8.42 \pm 0.19$ & $0.28 \pm 0.24$ & $5.08 \pm 1.75$ & $23.60 \pm 5.98$ & $71.32 \pm 5.83$ \\
April & $8.01 \pm 0.35$ & $0.86 \pm 0.20$ & $20.67 \pm 6.70$ & $49.11 \pm 14.76$ & $69.79 \pm 8.85$ \\
May & $7.73 \pm 0.59$ & $0.94 \pm 0.80$ & $4.39 \pm 0.85$ & $8.20 \pm 2.94$ & $87.41 \pm 3.25$ \\
June & $7.77 \pm 0.43$ & $0.85 \pm 0.23$ & $4.54 \pm 1.72$ & $5.77 \pm 3.51$ & $89.69 \pm 4.14$ \\
July & $7.35 \pm 0.43$ & $0.85 \pm 0.23$ & $30.15 \pm 5.84$ & $43.27 \pm 5.78$ & $73.42 \pm 5.07$ \\
August & $7.59 \pm 0.55$ & $0.75 \pm 0.14$ & $11.90 \pm 3.03$ & $28.22 \pm 4.51$ & $59.88 \pm 5.59$ \\
September & $7.41 \pm 0.31$ & $0.76 \pm 0.22$ & $13.45 \pm 3.80$ & $29.77 \pm 5.50$ & $56.77 \pm 5.14$
\end{tabular}

TOC: Total Organic carbon. Physico-chemical parameters are significant different between the seasons at $p<0.05$. Sediment grain sizes are significant different between the seasons at $p<0.05$.

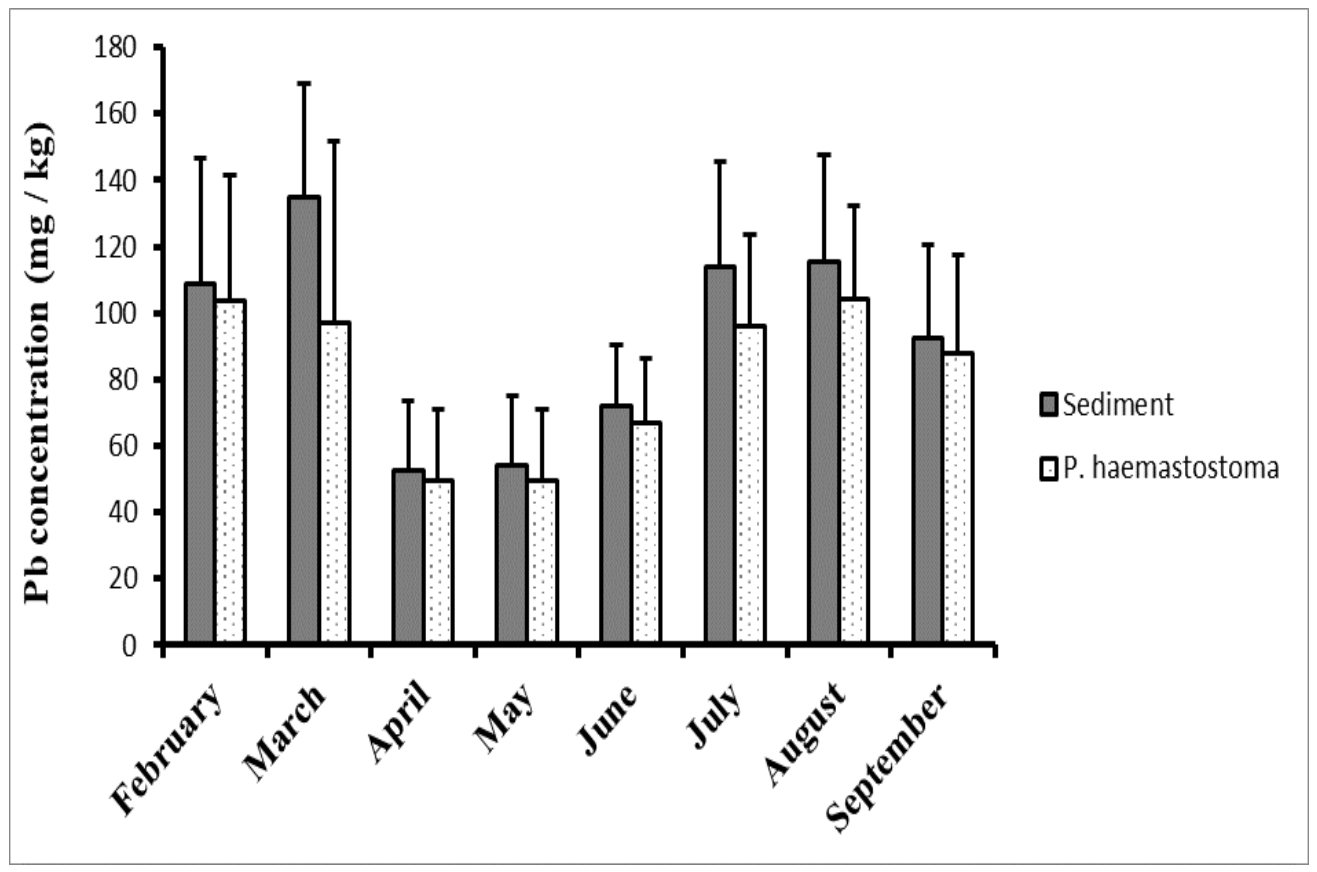

Figure 2: The concentration of lead (mg/kg dry weight) in sediment and in P. haemastostoma. $\mathrm{Pb}$ concentrations in sediment are significantly different between the seasons at $\mathrm{p}<0.05 ; \mathrm{Pb}$ concentrations in $P$. haemastostoma are significantly different between the dry and rainy, and, between the rainy and flood seasons at $\mathrm{p}<0.05$. 


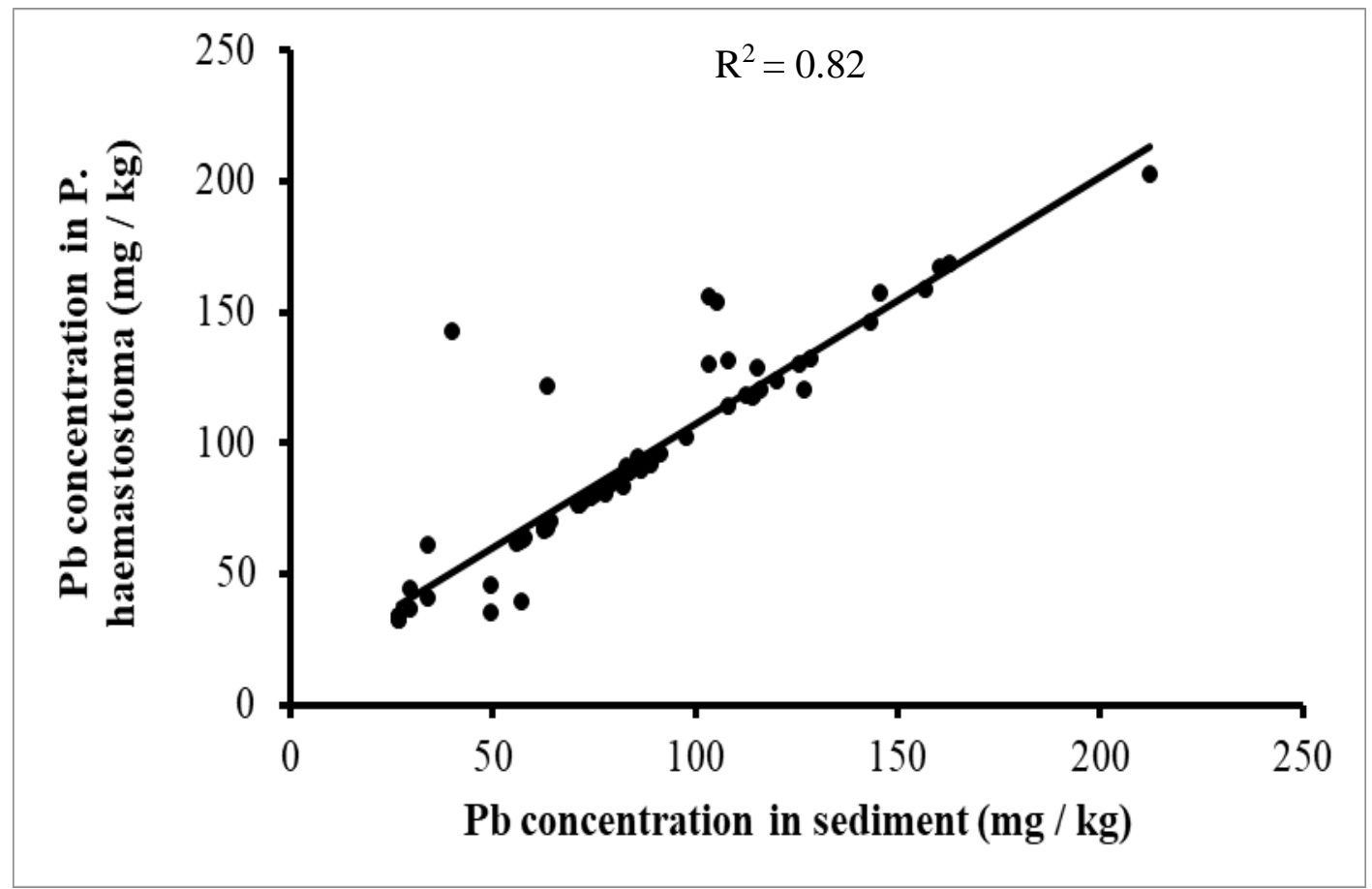

Figure 3: Linear regression between $\mathrm{Pb}$ concentration in sediment and $\mathrm{Pb}$ concentration in $P$. haemastostoma.

Correlation is significant at $\mathrm{p}<0.05$.

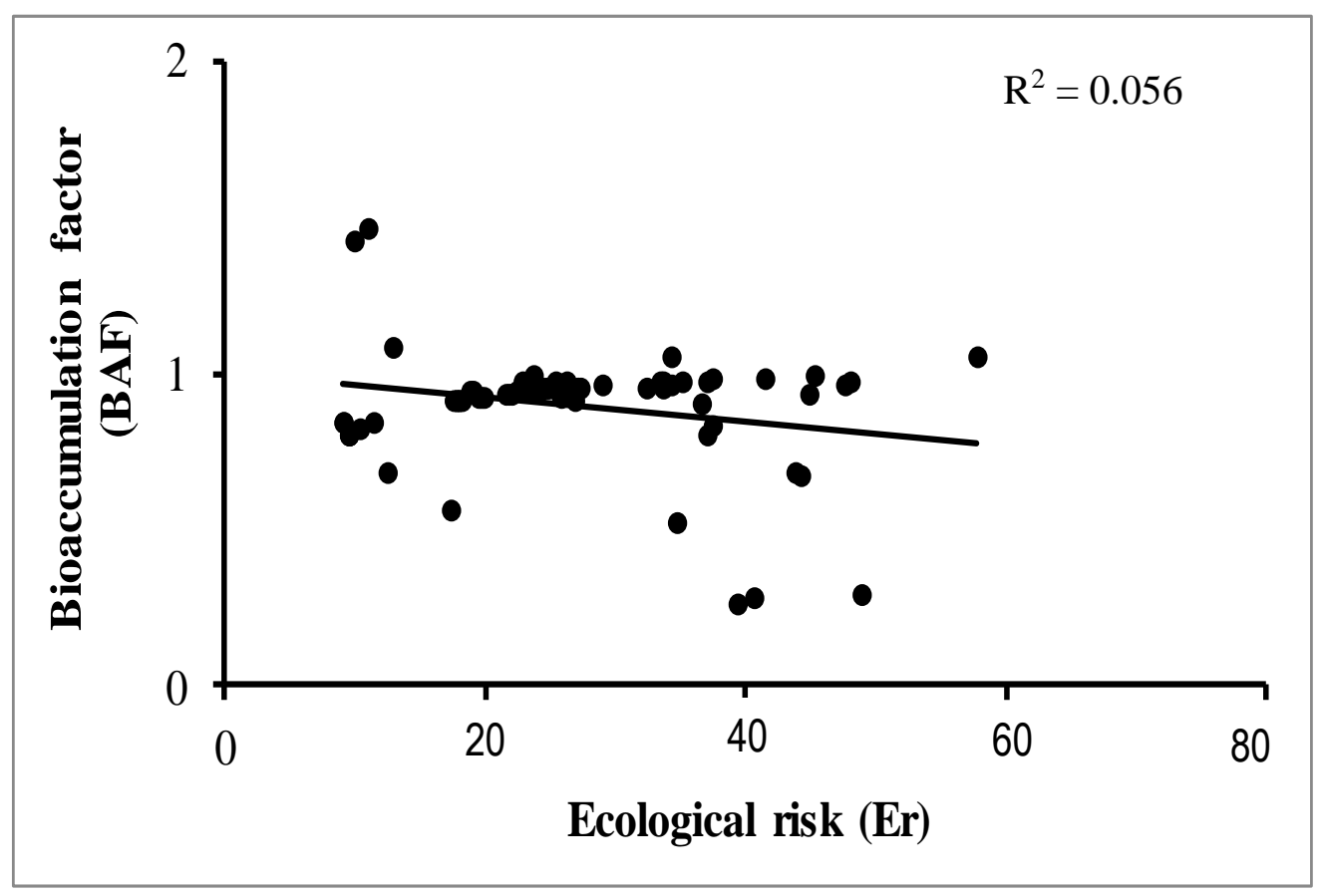

Figure 4: Linear regression between bioaccumulation factor $(B A F)$ and ecological risk index $\left(\mathrm{E}_{\mathrm{r}}^{\mathrm{i}}\right)$. 
Table 2: Results of bioaccumulation factor (BAF) and ecological risk index $\left(\mathrm{E}_{\mathrm{r}}^{\mathrm{i}}\right)$.

\begin{tabular}{lcl}
\hline & Er & BAF \\
\hline February & $32.01 \pm 11.17$ & $0.95 \pm 0.02$ \\
March & $39.62 \pm 10.06$ & $0.74 \pm 0.35$ \\
April & $15.48 \pm 6.15$ & $0.97 \pm 0.30$ \\
May & $15.96 \pm 6.15$ & $0.90 \pm 0.09$ \\
June & $21.24 \pm 5.40$ & $0.92 \pm 0.05$ \\
July & $33.45 \pm 9.43$ & $0.86 \pm 0.16$ \\
August & $33.93 \pm 9.43$ & $0.91 \pm 0.10$ \\
September & $27.13 \pm 8.33$ & $0.95 \pm 0.03$ \\
\hline
\end{tabular}

BAF: Bioaccumulation Factor; Er: ecological risk index of $\mathrm{Pb}$ in sediment; $\mathrm{Er}$ is significantly different between the seasons at $\mathrm{p}<0.05$.

\section{DISCUSSION}

\section{Physico-chemical parameters and sediment grain sizes}

Significant seasonal variability of physico-chemical parameters and sediment grain sizes was found between the dry season and the rainy and flood seasons. Vridi Canal is dominated by marine water from Atlantic Ocean. The intrusion of marine water increases pH values (Kumar et al., 2015). The $\mathrm{pH}$ values during the study period indicated that the surface sediments are basic character. This could be due to the contribution of marine water. A sedimentation medium usually has a pH between 6 and 8 . It has been reported that calcite is a carbonate mineral which is $\mathrm{pH}$ sensitive. In marine water $(\mathrm{pH}>$ 7), calcite is precipitated almost entirely. Therefore, it could be explained the basic character of sediment. In Vridi Canal, the dry season is characterized by the maximum intrusion of marine waters from the Atlantic Ocean which could explain the highest $\mathrm{pH}$ values. The low percentages of TOC obtained could be due to the sediments texture. In aquatic environment, fine particles (clays and silt) are responsible for the conservation of organic matter in sediments. These sediments are composed mainly of sand particles (Table 2). Therefore, they are poor in organic matter
(Chuan et al., 2016). Difference of fine particles content among the seasons could indicate that Vridi Canal receive different type of sediments. These sediments probably derived from anthropogenic discharges, weathering processes and Ebrie lagoon during the flooding season.

\section{Seasonal variation of $\mathrm{Pb}$ concentration in sediments}

$\mathrm{Pb}$ concentration in the sediments varied significantly during the seasons. Metal accumulation in sediment could be influenced by the physico-chemical parameters and the sediment grain sizes (Li et al., 2017). Our study showed seasonal variation of physicochemical parameters $(\mathrm{pH}, \mathrm{TOC})$ and fine particles (silt and clay), which could explain $\mathrm{Pb}$ seasonal variability in sediments. However, correlation analysis between physico-chemical parameters $(\mathrm{pH}, \mathrm{TOC})$, fine particles (silt and clay) and $\mathrm{Pb}$ concentrations in sediments should be conducted for further investigations in Vridi Canal. Seasonal variation of $\mathrm{Pb}$ was also reported in seafloor sediments from the East China Sea (Li et al., 2017), which corroborates our observations.

The high concentrations obtained during the dry and flooding seasons could be explained by the phenomena of adsorption 
due to the physico-chemical conditions. For example, the high $\mathrm{pH}$ in the dry season highly allows the fixation of $\mathrm{Pb}$ on sediments (Binkowski, 2017). Low concentrations of $\mathrm{Pb}$ in sediment during the rainy season (April to June) could be due to the diffusion phenomena (Binkowski, 2017). $\mathrm{Pb}$ concentrations obtained in this study could be compared with those found in marine sediments in Taiwan $(31-140 \mathrm{mg} / \mathrm{kg}$ ) (Chen et al., 2016) and in Australia (27-120 mg/kg) but higher than results reported by Vodopivez et al. (2015) (4.9-5.8 $\mathrm{mg} / \mathrm{kg})$ in marine sediments in Argentina, by El Taher et al. (2018) in Qusie seaport in Egypt $(48.2 \mathrm{mg} / \mathrm{kg}$ ) and by Choi et al. (2012) in HaengamMan seaport in South Korea $(29.3 \mathrm{mg} / \mathrm{kg})$. Accordingly, these results indicate that Vridi Canal could be considered as one of the most contaminated seaport area.

In this study, the significant high $\mathrm{Pb}$ concentrations in the sediments are probably originated from anthropogenic activities including waste disposal, maritime activities, and boat traffic (Bakary et al., 2015). Vridi Canal is the area where cruise boats and deep draft vessels daily transit the water of the harbour in Abidjan seaport (Kouakou et al., 2016a). It has been reported that the navigation of deep draft vessels leads to an intense sediment resuspension in seaport (Martínez-Soto et al., 2016). Therefore, input of $\mathrm{Pb}$ from sediments in Vridi Canal can occur by the sediment resuspension. $\mathrm{Pb}$ release from sediment could be accumulated by organisms such us gastropod species.

\section{Seasonal variation of $\mathrm{Pb}$ concentrations in $P$. haemastostoma}

$P$. haemastostoma is consumed by the surrounding population of Vridi Canal. The levels of $\mathrm{Pb}(26.83-212.28 \mathrm{mg} / \mathrm{kg})$ exceeded the maximum permissible levels $(2 \mathrm{mg} / \mathrm{kg}$ ) according to the United Nations Food and Agriculture Organization (FAO), indicating that it consumption constitute a risk for human consumption. $\mathrm{Pb}$ concentrations in $P$. haemastostoma were higher than those (1.16 -
$2.76 \mathrm{mg} / \mathrm{kg}$ ) in Ashtamudi estuary (India) by Ragi et al. (2017).

$\mathrm{Pb}$ concentrations in $P$. haemastostoma differed significantly from one season to another. The seasonal variation of $\mathrm{Pb}$ in gastropods might be due to the environmental conditions. It has been reported that when the environmental conditions fluctuate, the tolerance ranges and optima of organisms can shift or be exceeded; causing changes to the metal accumulation levels (Murray et al., 2013). In our study, sediments physicochemical parameters varied significantly according to the seasons. This could explain in part the seasonal variability of $\mathrm{Pb}$ concentrations in $P$. haemastostoma. Other factors such as age, size, growth cycle, and feeding habits could also influence $\mathrm{Pb}$ accumulation in gastropods species as reported by Xiaobo et al. (2009). Therefore, further studies in Vridi Canal including the effect of age, size and growth cycle will be necessary. Xiaobo et al. (2009) and Saha et al. (2016) observed that $\mathrm{Pb}$ levels in marine organisms were influenced by the seasons in Yangtze Estuary (China) and Bengal Bay (India), respectively, which corroborates our observations.

The total concentrations of $\mathrm{Pb}$ in $P$. haemastostoma and sediments showed similar seasonal patterns, because it was higher in the dry season, lower in the rainy season and medium in the flooding season. We concluded that $\mathrm{Pb}$ concentrations in the both matrices varied significantly among the seasons.

\section{Relationship between $\mathrm{Pb}$ in sediment and $\mathrm{Pb}$ bioaccumulation in $P$. haemastostoma} Molluscs are favoured as environmental monitors due to their sessile nature, cosmopolitan abundance and their ability to concentrate contaminants while maintaining a high tolerance (Xiaobo et al., 2009; Ragi et al., 2017). The extent of incorporation of $\mathrm{Pb}$ in soft tissues of the gasptropod from sediments depends on $\mathrm{Pb}$ concentrations in the sediments. Gastropod $P$. haemastostoma species are known to bioaccumulate contaminants (Kouakou et al., 
2016a) at water sediment interface via filter feeding. In this study, $\mathrm{Pb}$ accumulation in soft tissues of $P$. haemastostoma increased with the increasing total concentration of $\mathrm{Pb}$ in the sediments. The plausible pathway of $\mathrm{Pb}$ bioaccumulation by $P$. haemastostoma could be explained by the fact that aquatic organisms filter in and out surrounding water for food (Chakraborty et al., 2015). Sediments particles (suspended) in the water enter inside the organism during the filter finding. $\mathrm{Pb}$ associated with finer sediment particles also enters inside the organisms (Chakraborty et al., 2015).

A significant correlation also reported between $\mathrm{Pb}$ concentrations in the sediments and in P. haemastostoma showed that this specie accumulated $\mathrm{Pb}$ depending to its exposure to this metal. In addition, $P$. haemastostoma was sedentary, abundant in this study area and tolerant to high concentrations of $\mathrm{Pb}$ (Hamza-Chaffai, 2014). Based on the present evaluation which satisfied the criteria of bioindicator of metals pollution, $P$. haemastostoma can be used as bioindicators of pollution for lead.

\section{Ecological risk (Er) and Bioaccumulation factor (BAF)}

BAF is commonly used to estimate contaminant loads in aquatic organisms. BAF results indicated low tendency of $\mathrm{Pb}$ to be accumulated in the gastropod $P$. haemastostoma. These results might also indicate that $P$. haemastostoma present a lower level of bioconcentration, which could have a lower environmental impact on the studied aquatic ecosystem. Xiaobo et al. (2009) observed high tendency of $\mathrm{Pb}$ to be accumulated in gastropod $P$. Onchidium struma in Beibao Harbor (China), which not corroborates our findings. According to $\mathrm{Er}$ values no ecological damage should be observed at the $\mathrm{Pb}$ concentration in the sediments from Vridi Canal. This study also mentioned that $\mathrm{Pb}$ bioaccumulation factor was not correlated with its ecological risk index, suggesting that sediments possessing lower ecological risk may be resulting in lower tissue $\mathrm{Pb}$ of $P$. haemastostoma. Therefore, correlation between BAF and $\mathrm{Er}$ can be used to examine the transfer of $\mathrm{Pb}$ to sediment to $P$. haemastostoma in the Vridi Canal. We concluded that the higher concentrations of $\mathrm{Pb}$ observed in $P$. haemastostoma could be derived from others sources (e.g water and food). However, $\mathrm{Pb}$ chemical speciation study is necessary to better understand its fate, bioavailability and toxicity in seaport sediments.

\section{Conclusion}

This study has shown that $\mathrm{Pb}$ concentrations in sediments and P.haemastostoma varied significantly according to the seasons. Sediments and P.haemastostoma from Vridi Canal are highly contaminated by $\mathrm{Pb}$, indicating the influence of anthropogenic activities. The gastropod $P$. haemastostoma can be used as bioindicators of $\mathrm{Pb}$ pollution and it may be risky for human when it is consumed. This research also demonstrated that the correlation between bioaccumulation factor (BAF) and ecological risk index (Er) can be used to predict accumulation of $\mathrm{Pb}$ in gastropod $P$. haemastostoma in the Vridi Canal. However, for better understanding of $\mathrm{Pb}$ fate, bioavailability and toxicity, complementary study including $\mathrm{Pb}$ chemical speciation should be investigated.

\section{COMPETING INTERESTS}

The authors declare that they have no conflict to interest

\section{AUTHORS' CONTRIBUTIONS}

KAR, NLBK, EKK, AT, BKY and KA conceived and planned the experiments. KAR, EKK, carried out the experiments. KAR, NLBK, BKY, AT and KA planned and carried out the statistical analyses. KAR, NLBK, EKK, AT, BKY and KA contributed to sample preparation. KAR, NLBK, EKK, AT, $\mathrm{BKY}$ and KA contributed to the interpretation of the results. KAR and NLBK took the lead in writing the manuscript. All authors 
provided critical feedback and helped shape the research, analysis and manuscript.

\section{ACKNOWLEDGEMENTS}

We are thankful to the Centre de Recherches Oceanologiques (CRO) of Cote d'Ivoire for sampling. Unconditional help (to determination total metal concentration in the sediments and the gastropods by AAS) from the Director of INP-HB, Yamoussoukro, is gratefully acknowledged. Authors also acknowledge Dr. Nguadi Blaise Allou from Laboratoire de Chimie Physique, Université Félix Houphouët Boigny, Abidjan, Côte d'Ivoire, for agreeing to revise the English version of the manuscript. A special thank you goes to the reviewers for their critical contribution.

\section{REFERENCES}

Baby J, Raj JS, Biby ET, Sankarganesh P, Jeevitha MV, Ajisha SU, Rajan SS. 2010. Toxic effect of heavy metals on aquatic environment. Int. J. Biol. Chem. Sci., 4(4): 939-952. DOI: http://dx.doi.org/10.4314/ijbcs.v4i4.6297 6

Bakary I, Yao KM, Etchian OA, Soro MB, Trokourey A, Bokra Y. 2015. Zinc, copper, cadmium and lead concentrations in water sediment, and Anadara senilis in a tropical estuary. Environ Monit Assess, 187(12): 762-773. DOI: https://doi.org/10.1007/s10661015-4976-6

Baltas H, Sirin M, Dalgic G, Bayrak EY, Akdeniz A. 2017. Assessment of metal concentrations $(\mathrm{Cu}, \mathrm{Zn}$, and $\mathrm{Pb})$ in seawater, sediment and biota samples in the coastal area of Eastern Black Sea, Turkey. Mar. Pollut. Bull., 122(1-2): 475-482.

DOI:

https://doi.org/10.1016/j.marpolbul.2017 .06 .059

Binkowski LJ. 2017. The influence of environmental conditions on lead transfer from spent gunshot to sediments and water: Other routes for $\mathrm{Pb}$ poisoning. Chemosphere, 187: 330-337.
DOI:

http://dx.doi.org/10.1016/j.chemosphere. 2017.08.103

Berto $\mathrm{D}$, Brusà RB, Cacciatore $\mathrm{F}$, Covelli $\mathrm{S}$, Rampazzo F, Giovanardi O, Giani M. 2012. Tin free antifouling paints as potential contamination source of metals in sediments and gastropods of the southern Venice lagoon. Cont. Shelf. Res., 45: 34-41. DOI: http://dx.doi.org/10.1016/j.csr.2012.05.0 17

Botwe BO, Schamphelaere KD, Schipper CA, Teuchies J, Blust R, Nyarko E, Lens PN. 2017. Integrated hazard, risk and impact assessment of tropical marine sediments from Tema Harbour (Ghana). Chemosphere, 177: 24-34. DOI: http://dx.doi.org/10.1016/j.chemosphere. 2017.02.138

Chakraborty S, Chakraborty P, Nath BN. 2015. Lead distribution in coastal and estuarine sediments around India. Mar. Pollut. Bull., 97(1-2): 36-46. DOI: http://dx.doi.org/10.1016/j.marpolbul.20 15.05.056

Chen CF, Ju YR, Chen CW, Dong CD. 2016. Vertical profile, contamination assessment, and source apportionment of heavy metals in sediment cores of Kaohsiung Harbor, Taiwan. Chemosphere, 165: 67-79. DOI: http://dx.doi.org/10.1016/j.chemosphere. 2016.09.019

Chiffoleau JF. 2003. Dosage de Certains Métaux Traces :(Ag, $\mathrm{Cd}, \mathrm{Cr}, \mathrm{Cu}, \mathrm{Ni}, \mathrm{Pb}$, $V$, Zn) Dans les Organismes Marins par Absorption Atomique. Editions Quae: Versailles-France.

Choi KY, Kim SH, Hong GH, Chon HT. 2012. Distributions of heavy metals in the sediments of South Korean harbors. Environ. Geochem. Health., 34: 71-82. DOI: http://dx.doi.org/ 10.1007/s10653011-9413-3

Chuan OM, Chuen YJ, Mei FF. 2016. Determination of total organic carbon concentration in surficial sediments of Sungai Pinang, Penang, Malaysia. 
Malaysian Journal of Analytical Science, 20(6): 1318-1328. DOI: http://dx.doi.org/10.17576/mjas-20162006-10

El-Taher A, Zakaly HMH, Elsaman R. 2018. Environmental implications and spatial distribution of natural radionuclides and heavy metals in sediments from four harbours in the Egyptian Red Sea coast. Appl. Radiat. Isot., 131: 13-22. DOI: https://doi.org/10.1016/j.apradiso.2017.0 9.024

Gope M, Masto RE, George J, Hoque RR, Balachandran S. 2017. Bioavailability and health risk of some potentially toxic elements $(\mathrm{Cd}, \mathrm{Cu}, \mathrm{Pb}$ and $\mathrm{Zn})$ in street dust of Asansol, India. Ecotoxicol. Environ. Saf., 138: 231-241. DOI : http://dx.doi.org/doi:10.1016/j.ecoenv.20 17.01 .008

Hakanson L. 1980. An ecological risk index for aquatic pollution control. A sedimentological approach. Water Res., 14(8): 975-1001. DOI: https://doi.org/10.1016/00431354(80)90143-8.

Hamza-Chaffai A. 2014. Usefulness of bioindicators and biomarkers in pollution biomonitoring. Int. J. Biotech. Well. Indus., 3(1):19-26. DOI: http://dx.doi.org/10.6000/19273037.2014.03.01.4

Kantati YT, Kodjo MK, Gnandi K, Ketoh GK, Gbeassor M. 2013. Effects of pollution on oxidative stress in aquatic species: case of the fish Sarotherodon melanotheron in Bè Lagoon (Lomé). Int. J. Biol. Chem. Sci., 7(2): 717-725. DOI: http://dx.doi.org/10.4314/ijbcs.v7i2.26

Kouakou AR, Kouassi NLB, Yao BK, Trokourey A, Adouby K. 2016a. Heavy Metals in Sediments and Their Transfer to Edible Mollusc. J. Applied. Sci., 16: 534-541.

DOI: https://doi.org/10.3923/jas.2016.534.541

Kouakou AR, Yao B, Trokourey A, Kopoin A. 2016b. Assessment of Heavy Metals Contamination in Sediments of the Vridi Canal (Côte d'Ivoire). J. Geosci.
Environ. Protec., 4(10): 65-73. DOI : http://dx.doi.org/10.4236/gep.2016.4100 04

Kouassi NLB, Yao KM, Trokourey A, Soro MB. 2015. Distribution, Sources, and Possible Adverse Biological Effects of Trace Metals in Surface Sediments of a Tropical Estuary. Environ. Forensics, 16(1): 96-108. DOI : https://doi.org/10.1080/15275922.2014.9 91433

Kumar KSA, Priju CP, Prasad NBN. 2015. Study on Saline Water intrusion into the Shallow Coastal Aquifers of Periyar River Basin, Kerala using Hydrochemical and Electrical Resistivity Methods. Aquat. Procedia., 4: 32-40. DOI:

https://doi.org/10.1016/j.aqpro.2015.02.0 06

Li Y, Lin Y, Wang L. 2017. Distribution of heavy metals in seafloor sediments on the East China Sea inner shelf: Seasonal variations and typhoon impact. Mar. Pollut. Bull., 129(2): 534-544. DOI: https://doi.org/10.1016/j.marpolbul.2017 .10 .027 .

Martínez-Soto MC, Tovar-Sánchez A, Sánchez-Quiles D, Rodellas V, GarciaOrellana J, Basterretxea G. 2016. Seasonal variation and sources of dissolved trace metals in Maó Harbour, Minorca Island. Sci. Total. Environ., 565: 191-199. DOI: https://doi.org/10.1016/j.scitotenv.2016. 03.244

Mejdoub Z, Zaid Y, Hmimid F, Kabine M. 2018. Assessment of metals bioaccumulation and bioavailability in mussels Mytilus galloprovincialis exposed to outfalls pollution in coastal areas of Casablanca. J. Trace. Elem. Med. Biol., 48: 30-37. DOI : https://doi.org/10.1016/j.jtemb.2018.02.0 18

Radojevic M, Bashkin VN. 1999. Practical Environmental Analysis. Royal Society of Chemistry: Londres-Royaume-Uni. 
Ragi AS, Leena PP, Cheriyan E, Nair SM. 2017. Heavy metal concentrations in some gastropods and bivalves collected from the fishing zone of South India. Mar. Pollut. Bull., 118(1-2): 452-458. DOI:

https://doi.org/10.1016/j.marpolbul.2017 .03 .029

Saha N, Mollah MZI, Alam MF, Rahman S. 2016. Seasonal investigation of heavy metals in marine fishes captured from the Bay of Bengal and the implications for human health risk assessment. Food Control, 70: 110-118. DOI: http://dx.doi.org/10.1016/j.foodcont.201 6.05 .040

Saleem M, Iqbal J, Munir HS. 2015. Geochemical speciation, anthropogenic contamination, risk assessment and source identification of selected metals in freshwater sediments. -A case study from Manglav Lake, Pakistan. Environ. Nanotechnol. Monit. Manage., 4: 27-36. DOI :

https://doi.org/10.1016/j.enmm.2015.02. 002

USEPA. 2001 Methods for collection, storage and manipulation of sediments for chemical and toxicological analyses: technical manual. EPA Office of Water. EPA-823-B-01-002.

http://www.epa.gov/waterscience/cs/coll ection.html

Vodopivez C, Curtosi A, Villaamil E, Smichowski P, Pelletier E,Walter P, Cormack M. 2015 Heavy metals in sediments and soft tissues of the Antarctic clam Laternula elliptica: More evidence as a possible biomonitor of coastal marine pollution at high latitudes? Sci. Total. Environ., 502: 375384.

DOI :

http://dx.doi.org/10.1016/j.scitotenv.201 4.09.031

Wedepohl KH. 1995. The composition of the continental crust. Geochim. Cosmochim. Acta, 59(7): 1217-1232. DOI: https://doi.org/10.1016/00167037(95)00038-2
Xiaobo LI, Linzhi JIA, Yunlong Z, Qun W, Yongxu C. 2009. Seasonal bioconcentration of heavy metals in Onchidium struma (Gastropoda: Pulmonata) from Chongming Island, the Yangtze Estuary, China. J. Environ Sci., 21(2): 255-262. DOI: https://doi.org/10.1016/S10010742(08)62260-3

Xie M, Wang N, Gaillard JF, Packman AI. 2016. Hydrodynamic forcing mobilizes $\mathrm{Cu}$ in low-permeability estuarine sediments. Environ. Sci. Technol., 50(9): 4615-4623.

DOI : http://dx.doi.org/10.1021/acs.est.5b0457 6

Yao KM, Kouassi NLB. 2015. Etude des propriétés d'adsorption et de désorption du Plomb $(\mathrm{Pb})$ et du Cadmium $(\mathrm{Cd})$ par les sédiments d'une lagune tropicale en presence d'Allylthiourée. Int. J. Biol. Chem. Sci., 9(1): 483-491. DOI : http://dx.doi.org/10.4314/ijbcs.v9i1.41

Youssao A, Soclo HH, Bonou C, Fayomi B. 2011. Evaluation de la bioaccumulation $\mathrm{du}$ plomb dans les espèces animals marines et identification des sources de contamination métallique par une analyse multiélémentaire en métaux ( $\mathrm{Al}$, $\mathrm{Cd}, \mathrm{Cr}, \mathrm{Cu}, \mathrm{Pb}$ ) dans les eaux côtières du Bénin. Int. J. Biol. Chem. Sci., 5(1) : 188-195. DOI : http://dx.doi.org/10.4314/ijbcs.v5i1.6809 7

Zhang Y, Chu C, Li T, Xu S, Liu L, Ju M. 2017. A water quality management strategy for regionally protected water through health risk assessment and spatial distribution of heavy metal pollution in 3 marines reserves. Sci. Total. Environ., 599: 721-731. DOI : http://dx.doi.org/:10.1016/j.scitotenv.201 7.04.232. 